\title{
The impact of market exposure on public goods provision
}

Shami, Mahvish

Publication date:

2010

Document version

Publisher's PDF, also known as Version of record

Citation for published version (APA):

Shami, M. (2010). The impact of market exposure on public goods provision. Institute of Food and Resource Economics, University of Copenhagen. FOI Working Paper No. 2010/13

http://econpapers.repec.org/RePEc:foi:wpaper:2010_13 
INSTITUTE OF FOOD AND RESOURCE ECONOMICS

UNIVERSITY OF COPENHAGEN

\section{FOI Working Paper}

The Impact of Market Exposure on Public Goods Provision

Mahvish Shami 


\section{FOI Working Paper 2010 / 13}

The impact of market exposure on public goods provision Author: Mahvish Shami

Institute of Food and Resource Economics University of Copenhagen

Rolighedsvej 25

DK 1958 Frederiksberg DENMARK

www.foi.life.ku.dk 


\title{
The Impact of Market Exposure on Public Goods Provision
}

\author{
Mahvish Shami*
}

\begin{abstract}
Low levels of public goods provision in many developing countries' rural communities often force the poor to approach someone with considerable command over both financial and social resources to act as their patron. However engaging with the patron - typically a landlord - does not guarantee public provision, as inequality and lack of alternative options considerably weakens peasants' bargaining power, thus enabling the landlord to use peasant' votes to secure public resources for his own benefit. This paper proposes to increase peasants' bargaining power, and thus their ability to pressurize their patron to broker public goods for them, by increasing their alternative options through connectivity. In order to empirically test the viability of this solution the paper makes use of a natural experiment found in the construction of a motorway in Pakistan. Using household-level data, the study shows that households situated close to the road enjoy a significantly higher level of public investment when compared to similar peasants living in isolated villages. Moreover, the data finds the beneficial impact of connectivity is felt most strongly by the socially lower classes within rural society.
\end{abstract}

Key words: Public Goods Provision, Patron-Client Networks, Patronage Politics, Bargaining power, Pakistan

JEL classification: $H 41, R 2, O 1$

\footnotetext{
* Institute of Food and Resource Economics, University of Copenhagen, Rolighedsvej 25 Copenhagen 1958, Denmark, $\underline{\text { msh@foi.dk }}$

I would like to thank Dr. Jean-Paul Faguet, Lauge Poulsen and Hadia Majid for extensive comments on this paper. I would also like to thank the University of London Central Research Fund for funding data collection for this paper.
} 
The literature on economic development places considerable emphasis on public goods ${ }^{1}$ provision as a means of enhancing the welfare of the poor and reducing inequality. However, despite this concern, researchers have found that public investment in many developing countries is skewed in favours of wealthier 'elites' (see for example Banerjee and Somanathan 2007, Bardhan and Mookherjee 2002, Gazdar 2000, Charlton, et al. 2003). Elite capture has meant that public funds, which are ear-marked in the budget to alleviate poverty, are being appropriated for the benefit of the resource rich. This failure on the part of the state to provide for its citizens has meant that the poor are forced to pursue alternative avenues to fulfil their needs. Often this involves approaching someone who has command over considerable resources, both financial and social, and is willing to act as a patron (Scott1972, Powell 1970). Aligning with a patron does not, however, guarantee provision of public goods. Depending on the patron's bargaining power vis-à-vis citizens, clients might find themselves in a situation where the patron contracts with the local politician to secure public resources for his own private benefit in exchange for his clients' votes (Powell 1970, Keefer 2004, Scott and Kerkvliet 1977), leading to their exclusion from public spending decisions.

Thus the vulnerable groups in society, who are most in need of state resources, are most likely to get caught in a low-provision equilibrium. Efforts to alter this welfare reducing equilibrium can look at ways to change the relative bargaining powers in this relationship so as to empower clients to demand that the patron broker public goods for them. Bargaining power within the patron-client network, according to Scott and Kerkvliet (1977), is a function of the level of inequality and the number of options available to clients for satisfying their needs. Large scale inequality in developing countries has meant that most income generating assets are concentrated in a few hands forcing the resource poor to depend on them for earning a livelihood (World Bank 2000). Moreover, bad infrastructure has meant that rural areas tend to be isolated from the wider national economy, thus reducing the ability of the citizens to access the external market. Together, inequality and isolation make the patron a monopolist/monopsonist, able to exploit his position of privilege (Bhaduri 1977). Policies aiming to change the

\footnotetext{
${ }^{1}$ Public goods are defined not as pure public goods, rather as all goods provided by the state (Banerjee and Somanathan 2007).
} 
relative bargaining powers can then either focus on trying to reduce inequality or the level of isolation in rural economies.

Policies dealing with inequality - such as progressive taxes, welfare schemes and land reforms - are often politically contentious and difficult to implement, particularly in the short to medium term. High levels of corruption in developing countries have made tax evasion pervasive and funds meant for welfare enhancement tend to get appropriated by the elite. Furthermore, while some countries have had relative success with land reforms, others have been unable to implement a workable policy. It is also questionable whether land reforms alone are a welfare enhancing policy solution. While on the one hand peasants obtain control over a major income generating asset, thus allowing them to enjoy considerable economic independence, on the other it can create a vacuum in other aspects of their lives as patrons often perform functions the state is failing to do so (e.g. dispute resolution, social security, and sometimes even access to public goods) (Bardhan 1980).

As an alternative short to medium term solution, this paper proposes looking at policy options that reduce isolation and increase the number of options available to clients for satisfying their needs, thus breaking the monopoly/monopsony of the local patron. While there are a number of ways in which citizens can be provided with outside options, this paper explores the effect connectivity, through road networks, ${ }^{2}$ has on previously isolated rural economies. It is argued that road networks provide citizens with an exit option and thus alter the relative bargaining powers in rural societies. When faced with these new options patrons can respond in one of three ways. They can chose to do nothing in which case they are bound to lose their clientelist following. ${ }^{3}$ They can resort to violence and try to bar clients from engaging with the external market. While this could work in the short to medium term, it erodes peasant loyalty, thus becoming very costly in the long run (Scott \& Kerkvliet, 1977). A third possibility is that the patron can try and preserve his clientelist following by giving the peasants' needs due consideration.

\footnotetext{
${ }^{2}$ Connectivity can also be increased through telephone connections or access to computers and the internet (though this requires an educated population that is able to read and write).

${ }^{3}$ A breakdown of the existing patron-client network need not mean the end of clientelism. It might simply result in the poor establishing vertical links, possibly with different terms, with new actors in the economy (Scott and Kerkvliet 1977, Fox 1994).
} 
Making use of empirical data collected from rural Pakistan, the paper finds that connectivity does in fact alter the contract ${ }^{4}$ between the patron and the politician. Competition from the market has meant that the patron is no longer able to demand clients' votes without delivering some public goods in return.

The remainder of the paper is arranged as follows: Section 1 briefly outlines the main characteristics of patron-client networks, highlighting clients' low bargaining power in the presence of inequality and isolation. Section 2 discusses the perverse incentives clientelist networks create for politicians and the resultant welfare implications they have for poor citizens. Section 3 looks at the proposed solution of connectivity as a means of increasing clients' bargaining power so as to divert public resources towards satisfying their needs. Section 4 analyses empirical data collected from rural Hafizabad, Pakistan to evaluate whether the motorway has actually helped mitigate some of the harmful effects that patronage politics have on public goods provision and Section 5 concludes by outlining the major policy implications.

\section{Patron-Client Network - A Lopsided Friendship}

The patron-client relationship is a bond between a group of unequals born out of necessity and mutual benefit (Powell 1970, Scott and Kerkvliet 1977, Mason 1986). On the one hand, the network consists of clients who own very little, if any, assets and are under constant threat from fluctuations in their environment; both natural (diseases, famines, accidents and deaths) and manmade (threats of violence, injustice and exclusion) (Powell 1970). In order to try and ameliorate these hazards the peasant clients approach a figure of authority to act as their 'patron'.

The patron, on the other hand, is someone with a command over resources - both material and social. Due to his considerable wealth and social standing vis-à-vis the clients, he is able to ensure that at least the peasants' basic needs are met and that the household is protected against exploitation by a third party (Scott and

\footnotetext{
${ }^{4}$ This contract in an informal agreement between the patron and the local politician.
} 
Kerkvliet 1977). ${ }^{5}$ This is done by providing a number of services such as employment, social insurance, rent-free housing, low interest or interest free credit, protection from harassment, dispute resolution, access to the local politician and (sometimes but not always) provision of public goods (Scott 1972, Powell 1970). In return, the peasant is expected to provide the patron with economic, social and political favours and/or services. The client is, for instance, a source of cheap labour for the patron to use on his lands and in his house as domestic help. This work is often done at a wage below the market rate which helps the patron decrease his costs (Scott and Kerkvliet 1977, Ahmad 1977, Rouse 1988). The client moreover increases the social standing of the patron by being a member of his clientelist group; the more clients a patron has as followers the more powerful he is perceived to be. Lastly, peasants can provide the patron with political favours by agreeing to vote, without questions asked, for the candidate the patron supports (Scott and Kerkviet 1976), thus enabling the patron to wield considerable influence over politicians.

Peasants in rural communities are found to be disadvantaged in this relationship due to three interconnected reasons. Firstly, the needs (demands) of the peasants are fairly inelastic as they deal with goods and services vital to their survival, and they may have few other options for satisfying them (Scott \& Kerkvliet 1977). This is particularly true for landless households. ${ }^{6}$ The patron's demand curve, on the other hand, is relatively flat due to the large number of clients available to perform the tasks he needs done (Powell 1970, Mason 1986). ${ }^{7}$ Secondly, the resources of the patron are limited - sometimes they can be extremely limited ${ }^{8}-$ and have to be distributed over a large number of clients. Therefore, peasants need to compete, on the basis of their material wealth ${ }^{9}$ and social standing ${ }^{10}$, with one another to secure as much of the patron's resources as they can for themselves.

\footnotetext{
${ }^{5}$ This is not to say that the patron does not exploit them.

${ }^{6}$ Land owning households have a greater ability to satisfy their own needs and so are slightly better off (Scott 1976).

${ }^{7}$ This problem becomes severer with every generation due to population increase (Scott 1972).

${ }^{8}$ For instance, in Pakistan it was found that while these patrons/landlords are rich men in their villages, in cities they would be considered little more than glorified peasants.

${ }^{9}$ Some peasants might own a small amount of land or may own some livestock that can help generate some income.

${ }^{10}$ The social status of a peasant household may be determined by their kinship group or their caste or tribe.
} 
Hence, households which are socially and materially poor are least likely to benefit from patronage and are most vulnerable to exploitation.

Thirdly, the patron, due to his high level of control, is able to impose sanctions in the case of non-compliance. These sanctions can be economic, social and/or political in nature (Powell 1970). Economic sanctions can be imposed through employment termination, eviction and/or refusal of credit (Mason 1986). Ownership of the majority of land in rural societies gives the patron control over a major income generating asset, which means that a disagreement with him could result in exclusion from the main (and often sole) source of employment. Also, his land ownership could extend to peasants' homestead land and so defection of any form could very likely lead to eviction. ${ }^{11}$ Lastly, the patron can refuse to give the peasant credit which in agricultural economies, where income fluctuates considerably with the seasons, can be devastating.

Socially the patron can ostracise the peasant and his family, essentially barring them from availing the advantages of social insurance. In many developing countries, where there are no formal insurance mechanisms in place, the onus of protection falls mostly on society at large. Thus peasants rely on fellow citizens to come to their assistance when faced with idiosyncratic disasters (Dasgupta 1993). Ostracized households are left vulnerable to fluctuations in their environment as they are unable to tap into this network in times of need. Moreover, the patron can ensure that the peasant is excluded from any form of public goods provision. By virtue of his control over multiple votes, the patron can have considerable leverage over sitting politicians (see for example Scott1972, Powell 1970, Fox 1994) which can be used to persuade them to target public goods away from the defecting peasant (Rouse 1988). Cheema and Mohmand (2004), when studying Sargodha, Pakistan, found that households not aligned with the village influential (patron) were blatantly excluded from provision of goods such as drains and paved streets, even if they were situated in a neighbourhood patronized by the politician. ${ }^{12}$ Lastly if all else fails, the patron can impose his will on his client

\footnotetext{
${ }^{11}$ These rent contracts are informal in nature, therefore their terms can be altered at anytime.

${ }^{12}$ They found that drain systems would stop outside non-aligned households and start again from the next house. Clearly the functionality of the drain was not given much importance. The same was true of paved streets.
} 
through coercion and brute force. Scott and Kerkvliet (1977) argue that while this would ensure that peasants comply with the patron's wishes, it is likely to have an adverse effect on their loyalty towards the patron.

The patron's ability to impose these sanctions is influenced by two factors. First and foremost, his ability to coerce is dependent on the environment in which the relationship is cultivated. In isolated societies the patron has a high level of control as peasants have few, if any, outside options (Powell 1970, Basu 1983, Bhaduri 1977, Basu 1986). The patron, in this case, is often the main source of employment, the only source of credit, the provider of social insurance and the only link to the local politician. Provision of multiple services enables him to interlink markets, causing the outcome in one market to be jointly determined with the outcome in other markets (Basu 1986, Bell 1988, Bardhan 1980). ${ }^{13}$ This makes disagreements with the patron very costly as it can have consequences in multiple markets. Secondly, failure of governmental institutions in many developing countries has meant that the patron does not have to bear the consequences of certain activities (such as violence and extortion) that he otherwise would have had to if policing and the judiciary functioned better (Chabal and Daloz 1999). It also means that peasants have to rely on the patron for services which would normally be provided by the state (Weingrod 1968, Scott 1969, Cheema, et al. 2007, Ananthpur 2007, Krishna 2002).

Clearly this is a "lopsided friendship" (Pitt-Rivers 1954:140) with the patron having the advantage. While this has multiple consequences on the welfare of the peasant, this paper focuses on the impact this relationship has on political behaviour and the consequent outcomes in terms of public goods provision.

\section{The Deals Politicians Make}

Despite the well documented link between public goods provision and poverty alleviation, researchers have found that many developing countries continue to suffer from low levels of provision. This is particularly true of countries which are

\footnotetext{
${ }^{13}$ For an overview of the literature on interlinked markets see Bardhan (1980).
} 
young democracies. Keefer (2007) documents that as countries make the transition to democracy there is actually a fall in the level of provision enjoyed by citizens. This, at first, seems counter-intuitive as democracies are thought to perform better than non-democratic governments, as they set out to meet the needs of the majority who, in developing countries, are usually the poor rural communities (see for example Acemoglu and Robinson 2006, Baum and Lake 2001, Przeworski et. al. 2000, Sen 1999). An explanation to this conundrum can be found in the presence of patronage politics and the effect it has on the incentive structure for politicians.

Keefer (2007) highlights that one of the problems politicians face in young democracies is the inability to make credible pre-election commitments to their constituents. ${ }^{14}$ This makes campaigning very expensive and ineffective and therefore forces them to create alliances with someone who has credibility with the voters. In the presence of clientelist networks patrons can perform this function as, due to their face-to-face contact with peasants, they are perceived as being highly credible (Scott and Kerkvliet 1977, Powell 1970).

Aligning with the patron entails an exchange of votes - both of the patron and his clients - for certain services from the politicians. The patron is able to deliver a large number of votes as one of the services peasants provide to their patron is to agree to vote for the candidate he is supporting. This means that the patron in effect 'controls' a few hundred (if not more) votes which can be traded with politicians, as individual clients are unlikely to vote against the wishes of the patron due to fear of being sanctioned. This holds even when formal assurances of ballot secrecy are made, as peasants are unlikely to believe that their voting decisions are kept hidden from the patron (Mason and Joshi 2008). ${ }^{15}$ Politicians, in return, are expected to reciprocate by providing the patron with a combination of private goods (e.g. money, housing, land), targeted public goods (e.g. paved roads, drains, street lighting) and public goods for those clients who have relatively high bargaining power. As a result of this contracting, the politician is

\footnotetext{
${ }^{14}$ Political parties in young democracies do not have precedents that they can rely on to establish their credibility.

${ }^{15}$ As Mason and Joshi (2008) highlight this problem is even more pronounced in young democracies as peasants have no past experience of their decisions being kept secret from the patron.
} 
bound to become disengaged from the masses as any form of public spending has to be brokered through the patron, who in turn decides on the level of redistribution (Mason and Joshi 2008, Keefer 2007). ${ }^{16}$

Contracting with patrons is cheaper for the politician than providing public goods to the masses for two reasons. Firstly, in the presence of patronage politics the number of people politicians need to satisfy shrinks from a winning majority of constituents to a winning majority of patrons (Mason and Joshi 2008). Secondly, contracting with a patron guarantees results as defection on the part of the patron is easily detectable due to the large number of votes he controls. This is contrasted with contracting with citizens who, by virtue of constituting a minute fraction of the voting body, can renege (mostly by choosing not to vote) without detection (Keefer 2004). ${ }^{17}$ Contracting with the patron solves this problem and thus takes away the probabilistic nature of success in democracies. However, the disadvantage is that it significantly reduces the politician's incentive to spend public resources on poor constituents.

This is an ideal situation for both politicians and patrons. Provided politicians can contract with enough patrons, they can guarantee victory in an election, something they could never achieve in the absence of clientelist politics. For patrons this is yet another avenue through which to expropriate resources. The only losers are the clients with low bargaining power vis-à-vis their patron, who are unable to pressure him to include public goods provision for them in his contract with the politician.

\section{The Impact of Connectivity}

Given the aim of improving the welfare of the poor, it is worth exploring solutions to the low provision equilibrium found under clientelism. As mentioned above, the problem with patronage politics is that clients with low bargaining power are excluded from the contract between patrons and politicians. Therefore, solutions

\footnotetext{
16 Corruption, coupled with low levels of accountability, enables politicians to expropriate resources without having to face the consequences.

${ }^{17}$ Monitoring citizens' voting decisions, by the politician, is either not possible when balloting is secret, or prohibitively expensive when it is not as there are too many citizens.
} 
need to focus on ways of improving peasant bargaining power. These solutions can range from land reforms to fiscal policy initiatives to increasing the number of outside options available to peasants. As highlighted in the introduction, land reforms and fiscal policy reforms are politically contentious policies which have proven to be very difficult to implement.

As an alternative I propose looking at ways of increasing peasants' outside options so as to reduce their dependence on the patron. As mentioned in Section 1, poor peasants tend to have low bargaining power vis-à-vis the patron due to two interconnected factors; the relative inelasticity of their demands and the monopolistic/monopolistic powers of the patron resulting from isolation, both of which give him considerable leverage to dictate his terms. ${ }^{18}$ In order to increase peasants' bargaining power efforts need to be made to reduce their dependence on the patron by increasing their exit options (Mason 1986). The availability of multiple avenues for provision takes away the patron's ability to impose economic sanctions on the peasants. It also makes the threat of defection, on the part of the clients, more credible and one they can use to their advantage (Blok 1974, Weingrod and Morin 1971).

These alternative avenues can be created in two main ways - through government policy or market intervention. Government policy can be used to try to reduce the functions performed by the patron as most of these fall in the purview of state functionality. This calls for a reform initiative - for instance in the judiciary and the political system - so as to make government resources work better for the poor. This entails providing a viable avenue of conflict resolution, a more responsive police force and creating a political system that is more accessible, responsive and accountable to the masses. These reforms, however, are bound to be very expensive, both politically and financially, and unless implemented properly, run the risk of falling short of their objectives.

\footnotetext{
${ }^{18}$ Even if there are two or three patrons in the village that does not necessarily mean that the peasant has access to other patrons. For instance Platteau (1995) documents that in India age-old agreements between large patrons has meant that each may refuse to take in the others' defecting clients.
} 
A more viable alternative can be provided through the realm of market intervention, by reducing isolation that has been documented to increase the authority of the patron as it firmly establishes his monopoly in the village economy (see for example Powell 1970, Bhaduri 1977, Scott and Kerkvliet 1977). Connecting villages, through road networks, besides having a positive effect on agricultural productivity, has the ability to challenge the monopoly of the patron, thus reducing his authority over peasants. This could come through three main avenues; an increase in employment options, a possible influx of new patrons and an increase in the general level of awareness.

Connecting villages to the external market provides peasants with alternative forms of employment, ${ }^{19}$ - both in nearby towns and cities and within the villages, created by increased traffic - which the patron can neither influence nor control. These new employment opportunities have the potential to break the monopsony of the patron in the labour market, thus forcing him to offer terms at par with the market. This, besides leading to an increase in the peasants' standard of living, removes the patron's ability to use the threat of economic sanctions as a means of controlling them (Block 1974, Weingrod and Morin 1971). This economic emancipation should give the peasants added leverage to negotiate better terms, not just in the economic market, but also in other markets controlled by the patron.

The landlord has limited ability to either capture these new opportunities or to bar villagers from participating in them, as it would entail erecting a barrier on the road network so as to restrict traffic (and external traders) from coming to the village. The costs of doing this effectively would most often be extremely high almost prohibitive. Alternatively the patron could make use of violence to bar peasants from participating in the newly available market opportunities. However, besides having legal implications, this too is a costly option as it leads to a loss of peasant loyalty in an environment where peasants are valuable, at the very least, for their political support (Scott 1972). Therefore the costs borne by the patrons in

\footnotetext{
${ }^{19}$ It is important to note that the availability of new employment opportunities does not necessarily mean that the peasant will switch employment. The beneficial impact for the peasants might be the credible threat of defection that these new options provide, thus enabling them to negotiate better terms.
} 
trying to increase peasants' costs of approaching the external market would outweigh the benefits from such activities, and so peasants should experience an increase in their alternative options.

Furthermore, increased accessibility might also attract an influx of new actors wanting to take advantage of the villages' connectivity. ${ }^{20}$ This inflow could include potential new patrons who could provide peasants with a possible alternative to the current patron for provision (Rouse 1988). These new potential patrons create competition for existing patrons, possibly leading to an increase in services to the clients. ${ }^{21}$ One outcome of this competition may be for existing patrons to contract with the politician to direct public investment towards their clients. Lastly, connectivity can be expected to increase the level of awareness amongst peasants regarding their rights and the responsibility of the local politician towards them. These better informed peasants are more likely to demand public goods provision in exchange for their votes. ${ }^{22}$

Thus, through these multiple changes, connectivity should work to increase peasants' bargaining power and strengthen their position vis-à-vis the patron. While the increase in outside options is not likely to break the network as a whole, it should be enough to force the patron to give peasants' welfare due consideration. Specifically, in terms of public goods provision this would mean that in exchange for their votes peasants should now be able to demand some level of provision, thus forcing the patron to broker public goods for his clients.

\footnotetext{
${ }^{20}$ These new patrons need not be land owners. Rouse (1988) documents the emergence of a goldsmith as a new patron in Jalpana, Pakistan thus threatening the authority of the existing landlord.

${ }^{21}$ Since these are new patrons they are not bound by the age old agreement between patrons as found by Platteau (1995). It should be noted, however, that these new patrons might collude with existing ones so as to exploit the peasant rather than act as their competitors.

${ }^{22}$ Literature documents that an informed voter is much less likely to be ignored by politicians in their public spending decisions (see for example Prat and Strömberg 2006, Besley et. al. 2002, Besley and Burgess 2002, Olsen 1982).
} 


\section{Empirical Analysis}

Making use of a natural experiment found in Punjab, Pakistan this section tries to evaluate whether increased connectivity has, in fact, been able to increase public goods provision for peasants residing in villages dominated by a large patron.

Pakistan is a good case study for this analysis for two interconnected reasons. Firstly, it has in place extensive patron-client networks infiltrating into almost every aspect of villagers' lives (see for example Gazdar 2000, Ahmad 1977, Rouse 1988, Cheema and Mohmand 2006). Secondly, the country suffers from low levels of accountability and weak institutional structures, thus making it possible for politicians to appropriate public funds without having to face severe consequences (Keefer 2005). As Gazdar (2000) notes, these institutional flaws have meant that public goods in Pakistan are used more "as a currency for the disbursement of patronage" (pg. 77) than as a means for enhancing welfare.

What further makes Pakistan a good choice for this study is the motorway the federal government constructed in 1998, connecting Lahore (a major cosmopolitan city and the provincial capital of Punjab) to Islamabad (the capital of the country). Along the $365 \mathrm{~km}$ of this road there are multiple exits, each of which has a link road connecting the motorway to the nearest city/town. These link roads run past villages which were previously connected mostly by dirt trails which minimised traffic and restricted peasant mobility. Through its extensive network of link roads, the motorway has resulted in an increase in both peasant mobility, through an influx of cheap transport facilities, and travellers passing through the villages. While mobility allows peasants to explore employment options outside the village economy, increased traffic leads to new jobs being created within the village itself in the form of roadside cafes, vehicle repair shops, general stores, etc. Additionally, the motorway has had a positive spill-over effect on the level of awareness in the villages as exposure has meant an increase in information regarding the national economy.

The location of the motorway was determined by the federal government based on three main considerations - geography, connectivity and defence (Republic 
Engineering Corporation Limited 1988). ${ }^{23}$ Firstly, efforts were made to ensure that the road ran through as few geographical hazards as possible so as to minimise the risk of road accidents. ${ }^{24}$ Secondly, the federal government wanted to connect these two major cities with a motorway that was not very close to the old highway, and one which passed through as many towns and villages as possible without hampering the economic benefits to traders. ${ }^{25}$ Lastly, the Air Force has a bombing range situated between Lahore and Islamabad which made some of the suggested routes unusable. None of these factors are systematically related to specific village characteristics.

There were rumours however, that the placement of the road was changed from the original plan so as to allow it to run past the lands of large landlords. While I was unable to find evidence to confirm this, I identified areas where the motorway was not altered from the original plan in any way. Among these was Hafizabad, Punjab. In the area selected for this study the landlords, while commanding considerable authority in their own villages, would be considered part of the lower middle class in urban settings. This was quite evident from the houses they lived in, the cars they drove, the schools they sent their children to and their own levels of education. Therefore, they lacked the influence needed to alter the federal government's decision regarding the placement of a national highway. Hence the decision to make the motorway run through this area was independent of individual village level characteristics, making it an exogenous shock to the village economies and social relations.

\subsection{Methodology}

The empirical study makes use of data collected from household level surveys in villages located at varying proximity to the motorway ${ }^{26}$ to analyse the impact connectivity has had on public goods provision. The area chosen was Hafizabad

\footnotetext{
${ }^{23}$ Mr. Chaudry Muhammad Altaf, Chairman National Highway Authority, interview, 15 April 2008.

${ }^{24}$ Particular attention was paid to a salt range situated between Lahore and Islamabad, as passing through the salt range required the construction of winding roads which, it was believed, would increase the chances of motor accidents. Therefore the government wanted to minimise the stretch that ran through this area.

${ }^{25}$ The benefits of connecting additional towns and villages had to be weighed against the costs of the route between the two main cities being stretched to facilitate increased access.

${ }^{26}$ When talking about villages being close to the road, reference is made to their distance from a link road. The motorway itself is a fenced off road and presents no benefit to villages close to it.
} 
district in Punjab, Pakistan. ${ }^{27}$ The motorway passes though the district with two exits connecting it to nearby towns - Hafizabad City and Pindi Bhattian. ${ }^{28}$ Eight villages were chosen with four being situated close to the motorway link roads, while the other four were at a distance of between eight and eleven kilometres from the road. Travelling to distant villages took $40-90$ minutes by car from the motorway exit, due to the bad infrastructure. Moreover, interviews with households revealed that peasants often had to wait up to an hour to get a ride to the nearby town or city. Villages situated close to the motorway, on the other hand, are now highly accessible as they have experienced a substantial increase in the number of transport facilities available to them. Most households in such villages claimed to have to wait less than ten minutes to get a ride to the nearby town. ${ }^{29}$ This increased traffic has not only made it possible for villagers to travel to nearby towns and cities to look for work, but has also led to an increase in employment options within the villages themselves, focused on servicing passersby. Whereas $51 \%$ of households in connected villages felt that there had been an increase in employment opportunities outside the agricultural sector only $37 \%$ felt the same in isolated villages. ${ }^{30}$ This difference is significant at the $1 \%$ level.

Apart from the level of isolation, the villages also varied in the type of land tenure system in place. Hafizabad has historically had considerable variation in its land distribution making it possible to find villages where a single landlord owns the majority of the village resources (landlord dominated villages), as well as those where landholdings are spread over a considerable number of households, leading to the establishment of multiple patrons (peasant based villages). ${ }^{31}$ The distribution of land has a direct impact on the level of control the patron can exercise. In landlord dominated villages the patron, due to his large landholdings, has a greater level of control compared to a patron in peasant based villages, where dispersed land ownership has created multiple small patrons. However, it is worth mentioning that even in peasant based villages the incidence of landlessness

\footnotetext{
${ }^{27}$ Restricting the sample to villages within a district has the advantage of allowing us to rule out the possibility that differences in public investment could be driven by differences in the district's fiscal capacities.

${ }^{28}$ This study focuses on the exit to Hafizabad City.

${ }^{29}$ They also talked about the ride being extremely cheap.

${ }^{30}$ The agricultural sector is largely controlled by the patron.

31 Land distribution was historically determined by the British revenue collecting machinery making it exogenous to this model. For a discussion on land distribution under British rule over India, see Nelson (2010).
} 
is extremely high. The difference in these villages is that the multiplicity of patrons, each competing against the other to win the support of the peasant, enables the landless to have relatively higher bargaining power.

The choice to focus on villages with varying land tenure systems follows from Banerjee and Iyer's (2005) finding of low public investment in villages dominated by large landlords in comparison with relatively egalitarian ones. The expectation then is that connectivity should have a much stronger effect on landlord dominated villages than on peasant based ones. In order to evaluate the differential impact of connectivity on villages with differing land tenure systems, four of the eight selected villages are dominated by a large landlord while four are peasant based villages. Moreover, for each group, two villages have the link road run through them, while two are situated far away.

\begin{tabular}{l|c|c|}
\multicolumn{1}{c}{} & Landlord Dominated & Egalitarian \\
\cline { 2 - 3 } $\begin{array}{l}\text { Close to the } \\
\text { Motorway }\end{array}$ & 2 & 2 \\
\cline { 2 - 3 } & 2 & 2 \\
Far from the & & \\
Motorway & &
\end{tabular}

Landholdings of the patrons in landlord based villages varied between 100 and 300 acres. This land ownership often extended to the peasants' homestead land, making them rent-free tenants. Average landholding amongst the peasants in landlord dominated villages was 5.4 acres, ${ }^{32}$ with $55 \%$ of the population being landless. In peasant based villages the average landholding was 6.3 acres and 54\% households were landless. Monthly household expenditure was \$100 and \$103 in landlord and peasant based villages respectively. While $54 \%$ of households in landlord dominated villages were headed by an illiterate person, the corresponding figure in peasant based villages was $45 \%$. Moreover, each village had households belonging to both the upper and lower class biraderies (kinship groups).

\footnotetext{
${ }^{32}$ It is worth mentioning that these small landholders usually made use of family labour and thus did not provide an alternative form of employment for other peasants.
} 
Within the eight villages household level surveys were conducted by a team of 14 surveyors, supervised by myself, over a period of three months. The surveying process involved mapping the villages, ${ }^{33}$ identifying the biradery (kinship group) of each household and surveying a stratified random sample of $20 \%$ of the households. Stratification was done along biradery lines as literature on South Asia documents this as being a good proxy for social status (see for example Ahmad 1977, Cheema and Mohmand 2006). ${ }^{34}$ The aim was to ensure that the sample was representative of all biraderies so that no bias arose in the result due to over or under sampling of particular social groups. Within the villages visited the upper class biraderies were the Kharrals and the Bhattis. These were historically the land owning classes, which gave them their elevated status. However, a Kharral or a Bhatti household is considered upper class even if it is landless. The lower class households are comprised of the Muslim Sheikhs and the Ansaris. These biraderies were historically not allowed to own land. Interestingly, even though there is no legal restriction against them owning land today, almost all households of these biraderies are still landless. The status of Muslim Sheikh households is further lowered as this biradery is responsible for performing menial tasks which other households consider demeaning (such as cleaning the village drains). The biradery of the household is important as it influences its relationship with the patron. The upper class biraderies, besides having an elevated social standing, often also shared their biradery with the landlord, thus creating an extra tie to rely on.

The questionnaire used is broadly divided into four sections; public goods provision, politics, socio-political needs and household profile. The section on public goods asked questions pertaining to education, health, roads, paved streets and drainage systems. For each public good, questions were asked regarding the time of provision (before or after the construction of the motorway), who they believed was the intermediary that helped provide the good and how satisfied they were with the service.

\footnotetext{
${ }^{33}$ There are no official or unofficial maps of these villages. My maps are the first record of the layout of these villages, at least since 1947.

${ }^{34}$ For a detailed discussion on social stratification and biradery status in a Punjabi village see Ahmad (1977).
} 
The analysis in this paper is restricted to two public goods; paved streets and drainage systems. The reason for this choice lies in the nature of these goods and the way in which they are provided in Pakistan. Paved streets and drains in Pakistan are not 'pure' public goods. ${ }^{35}$ While they are non-rival, others can be excluded from their usage. This holds true even within a neighbourhood, where one would intuitively expect goods like paved streets and drainage systems to be non-excludable in order to be effective. However, this is not necessarily the case as a politician can exclude a single household from the provision of these goods even if the houses next door are being provided with them. ${ }^{36}$ This excludability makes these goods well suited for the purpose of this study.

Schooling and health care, the other main public goods, are not being considered for two interconnected reasons. Firstly, these goods are universal public goods, which once provided, are usually available for everyone to use. ${ }^{37}$ Secondly, these goods, as provided in rural Pakistan, are meant to service not only the village in which they are situated, but also other villages in its proximity. This means that restricting peasants' access would entail barring them from the usage of public goods found in other villages. This is difficult for the patron to ensure as his jurisdiction usually does not extend to other villages. ${ }^{38}$ Thus it is reasonable to assume that the patron and the politician do not enjoy the same level of control over these goods. The basic logistic regression models estimated are:

$\mathrm{Y}=\alpha+\beta_{1} \mathrm{MW}+\beta_{2} \mathrm{LL}+\beta_{3} \mathrm{Land}+\beta_{4} \mathrm{Bh}+\beta_{5} \cdot \mathrm{Kh}+\beta_{6} \mathrm{An}+\beta_{7} \mathrm{MS}+\xi$

$\mathrm{Y}=\alpha+\beta_{1} \mathrm{MW}+\beta_{2} \mathrm{LL}+\beta_{3} \mathrm{MW} * \mathrm{LL}+\beta_{4} \mathrm{Land}+\beta_{5} \mathrm{Bh}+\beta_{6} \mathrm{Kh}+\beta_{7} \mathrm{An}+\beta_{8} \mathrm{MS}+\xi$

$\mathrm{Y}$ is a binary variable taking the value of 1 if the household has a public good provided to it, 0 otherwise. Distance from the road, MW, takes the value of 1 if

\footnotetext{
${ }^{35}$ Pure public goods are non-rival - one person's use does not diminish the quantity available for another person - and are non-excludable - it is not possible to bar others from using it.

${ }^{36}$ Clearly the functionality of the drains and pavements were not taken into consideration. As long as a household was able to get the waste water out of their house and away from their front door, they were happy.

${ }^{37}$ Barring some peasants may require constant monitoring, which may be too costly and not worth the effort.

${ }^{38}$ While these patrons are big men in their own villages, in urban terms they belong to the lower class or lower middle class at best. Thus their influence, outside their own villages, is fairly limited.
} 
the household resides in an isolated village and 0 otherwise. Distance is analysed as a binary variable and not as a continuous one as the research design was to look at villages which were polar opposite, i.e. while half are situated close to the motorway the other half are far enough to be classified as being isolated. Within this setup modest changes in distance are irrelevant. ${ }^{39}$ LL is 1 if the household resides in a village dominated by a large landlord, 0 if it is in a peasant based village. Land is a continuous variable, measured in acres, capturing the amount of land owned by peasant households. This variable is included based on the argument that land owning households have higher bargaining power vis-à-vis the landlord as they are less dependent on him when compared to landless households (Scott 1976). Hence controlling for household land ownership allows us to test whether these households have greater access to public resources. The last four variables are dummies for the major biraderies found in the villages included as a control for the social status of the household (Ahmad 1977, Cheema and Mohmand 2006). Bh and $\mathrm{Kh}$ take the value of 1 is the household belongs to the Bhatti or Kharral biradery respectively. An is 1 if the household is an Ansari and MS is 1 if the households' biradery is Muslim Sheikh. The reference category is the small middle class biraderies. The variable $\mathrm{MW} * \mathrm{LL}$ in Equation 2 is an interaction term which captures the effect of belonging to a landlord dominated village far from the motorway. ${ }^{40}$

Connectivity is also expected to have a spillover effect on a household's level of awareness. It could be argued then, that the impact of the motorway on public goods provision, is not a direct one through an increase in peasants' bargaining power brought about by increased options, but rather an indirect effect channelled through increased awareness. This follows from the argument that an informed citizen is able to demand higher levels of public investment and should be able to put considerable pressure on politicians (see for example Prat and Strömberg 2002, Besley et. al. 2002, Besley and Burgess 2002, Olsen 1982). Hence it is possible that Equations 1 and 2 suffer from an omitted variable bias and are over-

\footnotetext{
${ }^{39}$ This research design was, amongst other things, driven by practical considerations, as trying to find the distance from the road after which villagers consider themselves isolated would have been extremely expensive and would have required looking at a large number of villages.

40 The inclusion of the interaction term in Equation 2 means that MW now captures the effect of the road on peasant based villages only; i.e. it assumes LL is taking the value of 0 . Similarly LL captures the effect of land tenure systems on villages close to the road only; i.e. when MW is 0 . The effect of that variable cannot be read off the table directly, as it requires further computation.
} 
estimating the effect of the road. Therefore the basic model is adjusted to include controls for levels of awareness:

$\mathrm{Y}=\alpha+\beta_{1} \mathrm{MW}+\beta_{2} \mathrm{LL}+\beta_{3} \mathrm{Land}+\beta_{4} \mathrm{~N}+\beta_{5} \mathrm{H}+\beta_{6} \mathrm{Bh}+\beta_{7} \mathrm{Kh}+\beta_{8} \mathrm{An}+\beta_{9} \mathrm{MS}+\xi$

Awareness is measured through two proxies; whether the household has access to a newspaper ${ }^{41}(\mathrm{~N})$ and whether the household has heard about local government participatory bodies $(\mathrm{H}){ }^{42}$ The local government ordinance in Pakistan has made provision for four participatory bodies which are meant to facilitate participatory development and to increase accountability of the politician. The aim of these bodies is to try to mobilize civil society. However, their functionality has been fairly limited, ironically due to citizens being unaware of their existence (Kurosaki 2007).

\subsection{Empirical Results}

Figure 1 illustrates the level of provision of drains and paved streets across the different types of villages. First off, we find that households situated in isolated landlord dominated villages have the lowest levels of provision, both for paved streets and drainage systems. Moreover the figure indicates that the effect of the road is stronger on provision in landlord dominated villages than peasant based ones. Dispersed land ownership in peasant based villages has meant that, even when isolated, peasants have alternative options in the form of other patrons and so no single patron is powerful enough to withhold public resources from his clients. In the case of landlord based villages close to the road, the availability of outside options has a similar effect, as it considerably weakens the influence of the landlord, which also restricts his ability to appropriate public funds. Thus the figure highlights that isolation and inequality alone do not adversely impact the level of public goods provision made to the peasants. Rather it is the interaction

\footnotetext{
${ }^{41}$ Access simply means they are able to get information from a newspaper, irrespective of whether they subscribe to it themselves, are reading it at a nearby shop or friend's house, or are having a friend read it to them (making it unnecessary for them to be literate).

42 The correlation between distance from the motorway and having heard about participatory bodies is -0.07 while the correlation between distance to the motorway and access to a newspaper is 0.03 . Thus there is little fear of multicolinearity biasing the results.
} 
between the two that creates a monopolistic/monopsonistic patron able to exclude peasants in his contract with the local politician.

The graphs also illustrate public spending, in all villages, being skewed towards the provision of drains rather than paved streets. The result seemed confusing at first, as villagers showed no preference for one over the other. ${ }^{43}$ There are two possible explanations for this. One could lie in the relative costs of the two goods. Drains in rural Punjab are almost never underground and at best may have been cemented to ensure that the waste does not flow onto the streets and goes straight to the main drain. ${ }^{44}$ This makes them easy and relatively cheap to construct. Paving streets, however, requires both materials and a certain level of skill. Given the limitation of funds, a politician wanting to reach the maximum number of constituents, may be more inclined to build drains than to pave streets. This seems to be the case in peasant based villages far from the road.

Figure 1: Public goods provision

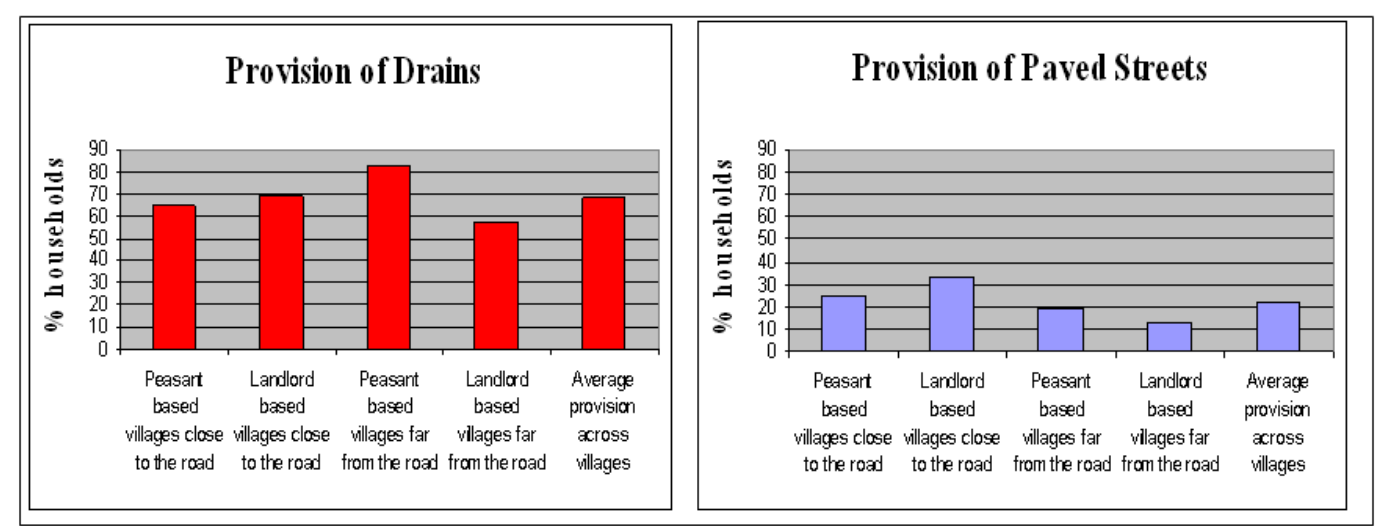

A second possible explanation lies in the interaction of drains with the streets. In the absence of a functioning drainage system, household waste flows directly onto the street outside their main door. Irrespective of whether the street is paved or not, this creates a mess and, besides spreading diseases, makes it difficult for people to move around. Mud (non-paved) streets, on the other hand, are not so much of a problem for mobility, provided they are not covered in dirty water and

\footnotetext{
${ }^{43}$ Households were asked what their three main needs were. When looking at the data for households without paved streets and drains, it was found that the number of households listing these two as their needs were relatively equal.

${ }^{44}$ The main drain, in all villages visited, is a big pond on one side of the village.
} 
household waste. ${ }^{45}$ Therefore, providing paved streets in areas without drains may not have the desired impact. The data show that of all the households provided with paved streets, only $23 \%$ lack drains.

The tables that follow test whether the effect of connectivity and land tenure systems on the households' chances of having public goods provided to them holds after controlling for household-specific characteristics. Table 1, in an effort to get an overall idea of the impact of connectivity and land tenure systems, inquires whether the household has had any public good provided to it. Column 1 presents the results using data pertaining to provision made before the construction of the motorway. This regression is run to test for endogeneity with respect to the motorway. The result is found to be negative, allowing us to rule out the possibility that there are some systematic differences between these eight villages in terms of public goods provision. Interestingly, from Column 1 we can see that the households' land ownership had a positive impact on its chances of receiving public goods prior to 1998. Each additional acre of land increases a household's chances of provision by $0.3 \%$. This result is significant at the $1 \%$ level. The small percentage effect per acre implies that the beneficial impact of land ownership accrues mostly to the medium and large landholders. This is not surprising when we consider that landed households have higher bargaining power vis-à-vis the patron when compared to the landless, as the patron is unable to impose economic sanctions on them. This implies that they can demand a higher level of public goods in exchange for their political support of the patron and the political candidate he aligns with.

Columns 2 to 4 look at provision made after the construction of the motorway. Starting with Column 2, we find that while the variable measuring isolation is insignificant, households residing in landlord dominated villages are 13\% less likely to have access to public provision when compared to those residing in peasant based villages. Introducing the interaction term in Column 3 reveals that it is actually households situated in landlord dominated villages far from the motorway who are most disadvantaged. These households are $23 \%$ less likely to

\footnotetext{
${ }^{45}$ I would like to thank Hadia Majid for bringing this point to my attention.
} 
have any public goods provided to them when compared to households in both peasant based villages and landlord based villages close to the motorway.

Table 1: Does the household have any public good provided to it?

\begin{tabular}{|c|c|c|c|c|}
\hline & $\begin{array}{c}\text { Pre- } \\
\text { Motorway } \\
\text { (1) } \\
\end{array}$ & $\begin{array}{c}\text { Post- } \\
\text { Motorway } \\
(2) \\
\end{array}$ & $\begin{array}{c}\text { Post- } \\
\text { Motorway } \\
\text { (3) } \\
\end{array}$ & $\begin{array}{c}\text { Post- } \\
\text { Motorway } \\
\text { (4) } \\
\end{array}$ \\
\hline $\begin{array}{l}\text { Household is situated in an } \\
\text { isolated village }\end{array}$ & $\begin{array}{l}-0.028 \\
(0.35)\end{array}$ & $\begin{array}{l}-0.037 \\
(0.488)\end{array}$ & $\begin{array}{c}0.089 \\
(0.277)\end{array}$ & $\begin{array}{c}0.093 \\
(0.252)\end{array}$ \\
\hline $\begin{array}{l}\text { Household belongs to a landlord } \\
\text { dominated village }\end{array}$ & $\begin{array}{r}0.0134 \\
(0.63)\end{array}$ & $\begin{array}{c}-0.113 * * \\
(0.02)\end{array}$ & $\begin{array}{c}0.005 \\
(0.844)\end{array}$ & $\begin{array}{c}0.004 \\
(0.874)\end{array}$ \\
\hline $\begin{array}{l}\text { Household resides in an isolated } \\
\text { landlord dominated village }\end{array}$ & & & $\begin{array}{c}-0.234 * * * \\
(0.002)\end{array}$ & $\begin{array}{l}-0.24 * * * \\
(0.002)\end{array}$ \\
\hline $\begin{array}{l}\text { Amount of land owned by the } \\
\text { household (acres) } \\
\text { Household has heard of } \\
\text { participatory bodies }\end{array}$ & $\begin{array}{l}0.0034 * * * \\
(0.003)\end{array}$ & $\begin{array}{c}0.00014 \\
(0.903)\end{array}$ & $\begin{array}{l}-0.0002 \\
(0.826)\end{array}$ & $\begin{array}{c}-0.0002 \\
(0.813) \\
0.027 \\
(0.682)\end{array}$ \\
\hline $\begin{array}{l}\text { Household has access to a } \\
\text { newspaper }\end{array}$ & & & & $\begin{array}{c}0.005 \\
(0.941)\end{array}$ \\
\hline Bhatti & $\begin{array}{l}0.0065 \\
(0.943)\end{array}$ & $\begin{array}{c}-0.0096 \\
(0.92)\end{array}$ & $\begin{array}{l}-0.059 \\
(0.544)\end{array}$ & $\begin{array}{l}-0.065 \\
(0.438)\end{array}$ \\
\hline Kharral & $\begin{array}{l}0.128^{*} \\
(0.051)\end{array}$ & $\begin{array}{l}-0.066^{*} \\
(0.096)\end{array}$ & $\begin{array}{l}-0.013 \\
(0.656)\end{array}$ & $\begin{array}{l}-0.017 \\
(0.653)\end{array}$ \\
\hline Ansari & $\begin{array}{c}0.153 \\
(0.161)\end{array}$ & $\begin{array}{c}-0.08 \\
(0.317)\end{array}$ & $\begin{array}{l}-0.077 \\
(0.331)\end{array}$ & $\begin{array}{l}-0.079 \\
(0.411)\end{array}$ \\
\hline Muslim Sheikh & $\begin{array}{l}-0.094 \\
(0.024) \\
\end{array}$ & $\begin{array}{c}-0.15 \\
(0.158) \\
\end{array}$ & $\begin{array}{l}-0.132 \\
(0.215) \\
\end{array}$ & $\begin{array}{r}-0.059 \\
(0.51) \\
\end{array}$ \\
\hline $\mathrm{N}$ & 383 & 383 & 383 & 383 \\
\hline $\mathrm{R}^{2}$ & 0.0329 & 0.0228 & 0.034 & 0.0314 \\
\hline
\end{tabular}

Isolation, combined with inequality, creates a monopolist/monopsonist landlord who is able to maintain a large clientelist following without having to broker political goods for them (Michie 1981). The same does not hold for villages connected to the motorway. The insignificance of the land tenure system variable in Column 3 illustrates that, when connected to the external market, the type of village that peasants reside in becomes unimportant for the purpose of public 
goods provision. These effects hold even after controlling for levels of awareness in Column 4. Lastly, when looking at provision made after the construction of the motorway, land owning households are no longer targeted for public goods provision as households' land holdings is found to be insignificant. The insignificance of this variable highlights the beneficial impact connectivity has had on landless households by reducing their disadvantage with regards to public spending decisions.

The table highlights the importance of land tenure system for public investment, as argued by Banerjee and Iyer (2005), but only as long as the villages are isolated. Once connected to the external economy, with all the options and opportunities that come with it, patrons are no longer able to ignore peasants in their contracts with politicians. Hence we find no evident disadvantage, regarding overall public goods provision, of living in a village dominated by a large landlord once connected to the road. However, given the differences between the provision of paved streets and drains, as illustrated in Figure 1, it is worth investigating the impact connectivity has had on these two goods separately. Moreover, following from the theoretical argument that households' economic and social disadvantages lower their bargaining power vis-à-vis the patron, thus negatively impacting their chances of provision, the tables that follow disaggregate the data by land tenure systems and distance from the motorway to evaluate who within the village is benefitting from connectivity.

As with overall provision, Table 2 first runs a test of endogeneity to check if there are any systematic differences based on geography, driving the differences in drainage provision. The result, as shown in Column 1, is found to be negative. However, what is significant is the households' land ownership, at the $1 \%$ level, on their chances of having drains provided to them prior to 1998.

Column 2 looks at provision made after the construction of the road, finding that it is land tenure systems and not distance from the motorway that significantly affects the probability of a household having drains provided. However, including the interaction term in Column 3 discloses that it is actually households residing in secluded landlord dominated villages who are most disadvantaged. These 
households have a $45 \%$ lower chance of having access to drainage systems when compared to both peasant based villages and landlord based villages situated on the road. Thus it seems that the monopoly/monopsony power enjoyed by the patron in isolated landlord based villages is enabling him to direct public resources away from the peasants and towards himself. While walking around these villages it was found that the area around the landlords' houses had perfectly paved streets and well functioning drains. However, as you moved away from their neighbourhood the quality of public goods provision tended to fall considerably.

Table 2: Does the household have drains?

\begin{tabular}{|c|c|c|c|c|}
\hline & $\begin{array}{c}\text { Pre-Motor } \\
\text { Way } \\
\text { (1) } \\
\end{array}$ & $\begin{array}{c}\text { Post- } \\
\text { Motorway } \\
(2) \\
\end{array}$ & $\begin{array}{c}\text { Post- } \\
\text { Motor way } \\
\text { (3) } \\
\end{array}$ & $\begin{array}{c}\text { Post- } \\
\text { Motor way } \\
\text { (4) } \\
\end{array}$ \\
\hline $\begin{array}{l}\text { Household is situated far from } \\
\text { the motorway }\end{array}$ & $\begin{array}{l}-0.003 \\
(0.946)\end{array}$ & $\begin{array}{l}-0.077 \\
(0.427)\end{array}$ & $\begin{array}{c}0.326^{* * *} \\
(0.006)\end{array}$ & $\begin{array}{l}0.32 * * * \\
(0.006)\end{array}$ \\
\hline $\begin{array}{l}\text { Household belongs to a landlord } \\
\text { dominated village } \\
\text { Household belongs to a landlord } \\
\text { dominated village far from the } \\
\text { motorway }\end{array}$ & $\begin{array}{c}0.025 \\
(0.517)\end{array}$ & $\begin{array}{l}-0.23 * * \\
(0.012)\end{array}$ & $\begin{array}{c}0.005 \\
(0.953) \\
-0.45 * * * \\
(0.00)\end{array}$ & $\begin{array}{c}0.013 \\
(0.884) \\
-0.44 * * * \\
(0.00)\end{array}$ \\
\hline $\begin{array}{l}\text { Amount of land owned by the } \\
\text { household (acres) } \\
\text { Household has access to a } \\
\text { newspaper }\end{array}$ & $\begin{array}{c}0.003 * * * \\
(0.002)\end{array}$ & $\begin{array}{c}0.005 \\
(0.341)\end{array}$ & $\begin{array}{c}0.003 \\
(0.412)\end{array}$ & $\begin{array}{c}0.004 \\
(0.367) \\
-0.005\end{array}$ \\
\hline $\begin{array}{l}\text { Household has heard of } \\
\text { participatory bodies }\end{array}$ & & & & $\begin{array}{l}(0.114) \\
0.096 \\
(0.268)\end{array}$ \\
\hline Bhatti & $\begin{array}{l}0.029 \\
(0.766)\end{array}$ & $\begin{array}{l}0.0365 \\
(0.75)\end{array}$ & $\begin{array}{l}-0.096 \\
(0.359)\end{array}$ & $\begin{array}{l}-0.108 \\
(0.315)\end{array}$ \\
\hline Kharral & $\begin{array}{c}0.172 \\
(0.037)\end{array}$ & $\begin{array}{l}-0.0383 \\
(0.759)\end{array}$ & $\begin{array}{c}0.15 \\
(0.103)\end{array}$ & $\begin{array}{c}0.130 \\
(0.154)\end{array}$ \\
\hline Ansari & $\begin{array}{c}0.186 \\
(0.132)\end{array}$ & $\begin{array}{l}-0.0829 \\
(0.653)\end{array}$ & $\begin{array}{c}0.053 \\
(0.783)\end{array}$ & $\begin{array}{c}0.059 \\
(0.763)\end{array}$ \\
\hline Muslim Sheikh & $\begin{array}{l}-0.092 \\
(0.153) \\
\end{array}$ & $\begin{array}{l}-0.142 \\
(0.41) \\
\end{array}$ & $\begin{array}{c}-0.12 \\
(0.495) \\
\end{array}$ & $\begin{array}{l}-0.113 \\
(0.529) \\
\end{array}$ \\
\hline $\mathrm{N}$ & 383 & 227 & 227 & 227 \\
\hline $\mathrm{R}^{2}$ & 0.0435 & 0.0666 & 0.0984 & 0.1046 \\
\hline
\end{tabular}


Furthermore, the significance of the isolation variable in Columns 3 and 4 reveals that the impact of the motorway is reversed on peasant based villages as far as drainage provision is concerned. Households residing in isolated peasant based villages have a higher probability of having drains provided to them. Patrons in these villages have been very active in securing drains for their clients, ${ }^{46}$ while those in connected peasant based villages chose to split public investment between the provision of drains and paved streets. ${ }^{47}$ These results hold even after controlling for households' level of awareness. While these results are interesting, it is curious that household specific characteristics are found to be insignificant. This could be due to the impact of these variables being averaged out in the aggregate data. Therefore, the effect of connectivity within the different villages may be more evident if we disaggregate the data. Table 3 does this by splitting the data four ways; by distance to the road and land tenure systems.

Starting with villages at varying distances form the road, we find that land tenure system matters for provision of drains, but only as long as the villages are isolated. Households living in isolated landlord dominated villages are $45 \%$ less likely to have drains provided when compared to equally secluded peasant based villages. Once connected to the road, the type of village the household resides in has no significant impact on its chances of provision. Secondly, while land ownership continues to matter for drainage provision in isolated villages, once connected by the road, landed households do not seem to enjoy the same advantage. Therefore, the evidence suggests that the increase in outside options has the same effect as land ownership, i.e. it provides households with alternative options for earning a livelihood, thus limiting the patrons' ability to impose sanctions. Lastly, the adverse effect of belonging to a socially lower class biradery is seen only in isolated villages. Muslim Sheikh households living far from the motorway are 50\% less likely to have drains when compared to any other biradery. Belonging to the Muslim Sheikh biradery in connected villages, however, has no significant effect. Furthermore, Ansari households are actually targeted for provision in villages close to the road, as they are $28 \%$ more likely to

\footnotetext{
${ }^{46}$ This can be seen from Figure 1.

${ }^{47}$ The local mayor has considerable discretion regarding the allocation of public funds between the various public goods in the villages. As mentioned earlier, in isolated peasant based villages the politician chose to invest mostly in drains while the politician in peasant based villages close to the road chose to split spending between drains and paved streets.
} 
have drainage provision, when compared to any other biradery. Interestingly, Bhatti households are $19 \%$ less likely to have drains when compared to other biraderies in isolated villages, significant at the $5 \%$ level.

Table 3: Does the household have drains?

\begin{tabular}{lcccc}
\hline & \multicolumn{4}{c}{ Drains provided post 1998 } \\
\cline { 2 - 5 } & $\begin{array}{c}\text { Close to } \\
\text { the Motor } \\
\text { Way } \\
\mathbf{( 1 )}\end{array}$ & $\begin{array}{c}\text { Far from } \\
\text { the Motor } \\
\text { Way } \\
\mathbf{( 2 )}\end{array}$ & $\begin{array}{c}\text { Landlord } \\
\text { Based } \\
\text { Villages } \\
\mathbf{( 3 )}\end{array}$ & $\begin{array}{c}\text { Peasant } \\
\text { Based } \\
\text { Villages } \\
\mathbf{( 4 )}\end{array}$ \\
\hline $\begin{array}{l}\text { Household is situated far from } \\
\text { the motorway }\end{array}$ & & $-0.21^{* *}$ & $0.24 * *$ \\
Household belongs to a landlord & 0.013 & $-0.45^{* * *}$ & $(0.014)$ & $(0.023)$ \\
dominated village & $(0.882)$ & $(0.00)$ & & \\
Amount of land owned by the & 0.0002 & $0.02^{* * *}$ & 0.001 & $0.024^{* * *}$ \\
household (acres) & $(0.935)$ & $(0.00)$ & $(0.797)$ & $(0.00)$ \\
Bhatti & -0.016 & $-0.197 * *$ & -0.05 & -0.096 \\
& $(0.871)$ & $(0.012)$ & $(0.577)$ & $(0.422)$ \\
Kharral & $0.24 * *$ & -0.097 & $0.22^{* *}$ & -0.019 \\
Ansari & $(0.016)$ & $(0.357)$ & $(0.019)$ & $(0.897)$ \\
& $0.28^{*}$ & -0.22 & $0.362^{* * *}$ & -0.132 \\
Muslim Sheikh & $(0.072)$ & $(0.249)$ & $(0.00)$ & $(0.398)$ \\
& 0.13 & $-0.50^{* * *}$ & -0.11 & -0.074 \\
$\mathrm{~N}$ & $(0.371)$ & $(0.00)$ & $(0.636)$ & $(0.784)$ \\
$\mathrm{R}^{2}$ & 111 & 116 & 103 & 124 \\
& 0.0378 & 0.2226 & 0.0718 & 0.1224 \\
\hline
\end{tabular}

Splitting the data by land tenure systems in Columns 3 and 4 illustrates the positive effect of connectivity on landlord dominated villages, as those residing close to the motorway are $21 \%$ more likely to have drains in comparison with isolated landlord dominated villages. Furthermore, within these villages, Kharral and Ansari households are $22 \%$ and $36 \%$ more likely to have drains compared to all other biraderies. While the higher level of provision to the Kharrals is not unexpected, given that they belong to the upper class, the increased provision to the Ansaris is. The data reveal that it is actually the Ansari households living close to the motorway in landlord dominated villages who are enjoying the higher levels of provision. This can also be seen from Column 1 which highlights the beneficial impact of being an Ansari household in villages close to the motorway. 
When focusing on peasant based villages we find that households situated in isolated peasant based villages are $24 \%$ more likely to have drains provided to them. This can be explained by the local politician's decision to provide drains in villages far from the road and not focus on paved streets. In villages connected by the motorway, as can be seen from Figure 1, the local politicians split resources between drainage provision and paved streets. ${ }^{48}$ Furthermore, in peasant based villages land ownership has a significant impact on the households' chances of having public goods provided to them. However, given the high levels of drainage provision in these villages, a substantial proportion of landless households have also been provided for. ${ }^{49}$ Lastly, it is interesting to find that in peasant based villages the households' biradery has no significant impact on its chances of having drains provided to them.

Turning next to the provision of paved streets, Table 4 analyses the impact of connectivity and land tenure systems on households' chances of receiving these goods. As before, Column 1 first runs a test of endogeneity to analyse if there are any systematic differences, based on location, between the eight villages, driving the differences in the provision of paved streets. The test is found to be negative. Moreover, as with drainage provision, the pre-motorway data finds that households' land ownership has a significant impact, at the $1 \%$ level, on their chances of having their streets paved. However, the level is not substantial.

Turning to provision after the construction of the motorway, we find that households situated in isolated villages are $13 \%$ less likely to have their streets paved. Including the interaction term in Column 3 does not take away the significance of the motorway variable, highlighting the positive impact that connectivity has had on peasant based villages. The interaction term itself though,

\footnotetext{
${ }^{48}$ Since paving streets is more expensive than the provision of drains the exchange is not one to one. Moreover, the decision regarding which of the two goods to provide is purely up to the politician. As far as the villagers are concerned, due to low levels of provision and their resultant low expectations, they are happy as long as some public good is provided to them.

${ }^{49} 65 \%$ of landless households had a drain provided to them in peasant based villages.
} 
is insignificant. Furthermore, the positive impact of the motorway continues to hold even after controlling for levels of awareness in Column $4 .{ }^{50}$

Table 4: Does the household have paved streets?

\begin{tabular}{lcccc}
\hline & $\begin{array}{c}\text { Pre- } \\
\text { Motorway } \\
\mathbf{( 1 )}\end{array}$ & $\begin{array}{c}\text { Post- } \\
\text { Motorway } \\
(\mathbf{2})\end{array}$ & $\begin{array}{c}\text { Post- } \\
\text { Motorway } \\
\mathbf{( 3 )}\end{array}$ & $\begin{array}{c}\text { Post- } \\
\text { Motorway } \\
\mathbf{( 4 )}\end{array}$ \\
\hline $\begin{array}{l}\text { Household is situated in an } \\
\text { isolated village }\end{array}$ & -0.017 & $-0.13^{* *}$ & $-0.083^{*}$ & $-0.084^{* *}$ \\
Household belongs to a landlord & $(0.514)$ & $(0.021)$ & $(0.057)$ & $(0.022)$ \\
dominated village & 0.015 & -0.0018 & 0.027 & 0.027 \\
Household resides in an isolated & $(0.489)$ & $(0.973)$ & $(0.737)$ & $(0.725)$ \\
landlord dominated village & & & -0.0769 & -0.075 \\
Amount of land owned by the & $0.0006^{* *}$ & 0.0004 & 0.0003 & $(0.285)$ \\
household (acres) & $(0.026)$ & $(0.482)$ & $(0.478)$ & 0.0004 \\
Household has access to a & & & & $-0.953)$ \\
newspaper & & & & $(0.469)$ \\
Household has heard of & & & & 0.003 \\
participatory bodies & & & & $(0.59)$ \\
& & & & 0.006 \\
Bhatti & -0.019 & 0.0252 & 0.0065 & $(0.93)$ \\
& $(0.329)$ & $(0.678)$ & $(0.919)$ & 0.01 \\
Kharral & -0.039 & -0.003 & 0.011 & $(0.79)$ \\
& $(0.292)$ & $(0.935)$ & $(0.802)$ & -0.032 \\
Ansari & -0.038 & -0.033 & -0.0316 & $(0.601)$ \\
& $(0.338)$ & $(0.596)$ & $(0.603)$ & -0.056 \\
Muslim Sheikh & -0.028 & -0.061 & -0.056 & $(0.467)$ \\
\hline $\mathrm{N}$ & $(0.533)$ & $(0.437)$ & $(0.466)$ & 346 \\
$\mathrm{R}^{2}$ & 383 & 346 & 346 & 0.0544 \\
\hline
\end{tabular}

Robust standard errors calculated. P-values in parentheses $* * * \mathrm{p}<0.01,{ }^{* *} \mathrm{p}<0.05,{ }^{*} \mathrm{p}<0.1$

To sum up, the tables above highlight three important and interconnected findings. Firstly, as argued by Banerjee and Iyer (2005), land tenure system matters for public investment, but only if villages are isolated. Isolated villages dominated by a large landlord are less likely to be provided with public goods when compared to those with a relatively egalitarian distribution of land. In peasant based villages, on the other hand, dispersed land ownership has led to the existence of a large number of patrons, each too small to exert significant control

\footnotetext{
${ }^{50}$ The lack of substantial variation in the results could be explained by the fact that paved streets are not a widely provided public good, as is evident from Figure 1. The same was found when the data were disaggregated and so it is not presented here.
} 
over the peasants. Therefore, in order to maintain their cliental following patrons need to offer their clients goods and services (Michie 1981). One outcome of this is for the patron to include provision to his clients in his contract with the politician. Patrons in landlord dominated villages do not feel the same constraints, as their large land holdings give them monopoly/monopsony power over the landless peasants (Bhaduri 1977, Michie 1981). The clients whose needs patrons cater for in these villages are those who are economically and socially better off in society and thus have some leverage over the patron.

Secondly, being connected by a motorway significantly increases the average household's chances of having public goods provided to it. This effect is felt more strongly by peasants residing in villages dominated by large landlords than those living in peasant based villages. The presence of alternative options, at least in the employment market, has created competition for the large patrons, as it restricts the patron's ability to impose economic sanctions, thus leading to a shift in relative bargaining powers in favour of the rural poor. As a result, the landlord is forced to broker public goods for his clients, as otherwise he runs the risk of losing his clientelist following (Scott and Kerkvliet 1977). Thus connectivity is enabling outcomes in landlord dominated villages to converge to those found in their peasant based counter-parts.

Lastly, connectivity, and the increase in outside options that come with it, is found to benefit the socially and economically lower classes of village society. These are those members of society who are most dependent on the patron's resources and, ordinarily, are least likely to withdraw their support from him due to underprovision. However, as the construction of the motorway has provided these households with a viable alternative means of employment, the patron can no longer expect their unwavering support in the face of under-provision. Therefore the patron has had to channel some of the resources contracted with the politician towards them, leading to an increase in their overall welfare.

\section{Conclusion}


Literature on rural development documents the importance of public goods provision in reducing inequality, yet there is wide spread evidence of underprovision. While efforts have been made by governments to improve provision, inefficiency, corruption, elite-capture and patronage politics have meant that they have failed to achieve the desired results (see for example Banerjee and Iyer 2005, Bardhan and Mookherjee 2002, Gazdar 2000, Charlton, et al. 2003). This paper has argued that the presence of patron-client networks has eroded the politicians' incentive to provide for their constituents directly, as they are able to guarantee success by contracting with local patrons. Thus any provision that is made is brokered through a patron (Mason and Joshi 2008, Keefer 2007). The outcome of this has been that public goods provision to peasants largely depends on their bargaining power vis-à-vis the patron. Large scale inequality has allowed patrons to enjoy considerably higher bargaining power, enabling them to direct most public funds towards themselves. This situation is made considerably worse by the isolated nature of many rural societies, facilitating the establishment of a monopolist/monopsonist patron (Bhaduri 1977).

This paper has explored the possibility of increasing peasants' bargaining power by connecting isolated villages to the wider national economy through road networks. The motorway has led to a significant increase in traffic passing through villages, enabling villagers to take advantage of employment opportunities centred around servicing passing traffic. Moreover, with increased traffic the villagers have greater transport facilities available at fairly reasonable prices making it possible for them to travel to nearby towns and cities to find employment. The data show that, while most households did not choose to seek employment outside the village, a substantial proportion felt that they had the option available to them. These new options have made peasants feel less dependent on the patron and thus enabled them to question why their votes are not translating into increased public goods provision.

The welfare implications of road networks, as found in this paper, are two-fold. There is an intended effect on the economic circumstances of the peasant household, in the form of increased employment opportunities. This helps break the monopsony of the landlord in the labour market, thus giving peasants the 
ability to negotiate better terms. Secondly, the motorway has a spill-over effect on the social dynamics within the villages. The breakdown of the patron's monopoly/monopsony power should lead to an increase in the peasants' bargaining power which they can use to make demands on the patron. This can be seen through the higher level of provision enjoyed by villagers close to the motorway, indicating that connectivity has resulted in the patron altering his contract with the local politician so as to increase provision towards the peasants. These benefits are being felt most by the landless and the socially lower classes who are most vulnerable in village society and are most likely to be excluded by a monopolistic patron.

The policy implication drawn from this study is quite clear - it is imperative to connect rural villages to the outside economy so as to break their isolation and thus reduce the exploitative powers of the resource rich patrons. Road networks are one way to do this. The advantage of this policy option is two-fold. Firstly, it provides rural economies with much needed infrastructural development, which is bound to have a positive effect on agricultural growth rates. Secondly, it is not a politically contentious policy, as each actor in the economy has something to gain from it, making it easy for politicians to implement. Clients benefit as it enhances their mobility and creates alternative options for them. Landlords also profit because it increases the value of their land and makes it easier for them to travel back and forth. Lastly, road networks are 'big impact' projects which politicians can use in the next election to show their commitment towards providing for their constituents. $^{51}$

This paper gives a relatively easy and effective policy option that can help alter the bargaining powers in favour of the peasants, thus improving their welfare. However, this is not to say that building roads is the sole solution to the age old development problem. Looking at the levels of provision in villages close to the motorway, it is obvious that even the 'fortunate' ones have very low levels of provision. However, what the road does do is provide the stimuli needed to change the power dynamics in rural villages which, in turn, enables villagers to

\footnotetext{
${ }^{51}$ Politicians can, and do, claim credit for the construction of the road even though they had nothing to do with the decision making process.
} 
FOI Working Paper 2010/13

start demanding their rights. Hence it is a first step on the long road to development. 


\section{Bibliography}

Acemoglu, D. and J. A. Robinson (2006). "De Facto Political Power and Institutional Persistence." American Economic Review 96(2): 325-330.

Ahmad, S. (1977). Class and power in a Punjabi village. New York Monthly Review Press.

Alavi, H. (1972). "Kinship in West Punjab Villages " Contributions to Indian Sociology 6: $1-27$.

Ali, I. (1988). The Punjab Under Imperialism. Princeton Princeton University Press.

AnanthPur, K. (2007). "Rivalry or Synergy? Formal and Informal Local Governance in Rural India." Development and Change 38(3): 401-421.

Banerjee, A., L. Iyer, et al. (2005). "History, Social Divisions, and Public Goods in Rural India." Journal of the European Economic Association 3(2-3): 639-647.

Banerjee, A. and R. Somanathan (2007). "The political economy of public goods: Some evidence from India." Journal of Development Economics 82(2): 287-314.

Bardhan, P. (1980). "Interlocking Factor Markets and Agrarian Development: A Review of Issues." Oxford Economic Papers 32(1): 82-98.

Bardhan, P. and D. Mookherjee (2002). Relative Capture of Local and Central Governments: An Essay in the Political Economy of Decentralization. Centre for International and Development Economics Research. Berkley, University of California: 99-109.

Bardhan, P. and D. Mookherjee (2006). "Pro-poor targeting and accountability of local governments in West Bengal." Journal of Development Economics 79(2): 303-327.

Basu, K. (1983). "The Emergence of Isolation and Interlinkage in Rural Markets." Oxford Economic Papers 35(2): 262-280.

Basu, K. (1986). "One Kind of Power." Oxford Economic Papers 38: 259-282. 
Baum, M. A. and D. A. Lake (2003). "The Political Economy of Growth: Democracy and Human Capital." American Journal of Political Science 47(2): 333-347.

Bell, C. (1988). Credit Markets and Interlinked Transactions. Handbook of Development Economics H. Chenery and T. N. Srinivasan, Elseneia Science Publishers.

Besley, T. and R. Burgess (2002). "The Political Economy of Government Responsiveness: Theory and Evidence from India." The Quarterly Journal of Economics 117(4): 1415-1451.

Besley, T., R. Burgess, et al. (2002). Mass Media and Political Accountability. The right to tell: the role of mass media in economic development. R. Islam, S. Djankov and C. McLiesh. Washington D.C., The World Bank.

Bhaduri, A. (1977). "On the formation of usurious interest rates in backward agriculture." Camb. J. Econ. 1(4): 341-352.

Chabal, P. and J.-P. Daloz (1999). Africa works : Disorder as Political Instrument. Oxford, International African Institute in association with James Currey,.

Charlton, J., N. Manning, et al. (2003). Devolution in Pakistan - Preparing for Service Delivery Improvements. Forum on Intergovernmental Relations and Service Delivery in Pakistan, World Bank-ADB-DfID.

Cheema, A. and S. Mohmand (2004). Local Government Reforms in Pakistan: Legitimising Centralisation or a Driver for Pro-Poor Change. Structural Impediments to Pakistan's Development. H. Gazdar and A. U. Sayeed. Karachi, Oxford University Press.

Cheema, A., S. Mohmand, et al. (2007). History, Land Settlements and Informal Institutions in Sargodha. Informal Institutions Project. Sussex, LUMS-DRC.

Dasgupta, P. (1993). An inquiry into well-being and destitution Oxford, Clarendon Press.

Fox, J. (1994). "The Difficult Transition form Clientelism to Citizenship: Lessons from Mexico." World Politics 46(2): 151-184. 
Gazdar, H. (2000). State, Community, and Universal Education: a Political Economy of Public Schooling in Rural Pakistan. London, London School of Economics and Political Science. $\mathrm{PhD}$.

Keefer, P. (2004). Clientelism, Credibility and Democracy. Development Research Group. Washington DC, World Bank.

Keefer, P. (2007). Insurgency and credible commitment in autocracies and democracies, The World Bank.

Krishna, A. (2002). Active Social Capital. New York, Columbia University Press.

Kurosaki, T. (2007). "Community and Economic Development in Pakistan: The Case of Citizen Community Boards in Hafizabad and Japanese Perspectives." Pakistan Development Review 45(4).

Mason, T. D. (1986). "Land Reform and the Breakdown of Clientelist Politics in El Salvador." Comparative Political Studies 18(4).

Mason, T. D. and M. Joshi (2008). "Between Democracy and Revolution: Peasant Support for Insurgency versus Democracy in Nepal " Journal of Peace Research 45.

Michie, B. H. (1981). "The Transformation of Agrarian Patron-Client Relations: Illustrations from India." American Ethnologist 8(1): 21-40.

Olsen, M. (1982). The Rise and Decline of Nations. New Haven and London, Yale University Press.

Pitt-Rivers, J. (1954). The People of the Sierra. New York, Criterion Books.

Powell, J. D. (1970). "Peasant Society and Clientelist Politics." The American Political Science Review 64(2): 411-425.

Prat, A. and D. Strömberg (2006). Commercial Television and Voter Information, UCLA Department of Economics. 
Przeworski, A., M. E. Alvarez, et al. (2000). Democracy and Development: Political Institutions and Well-Being in the World, 1950-1990 New York, Cambridge University Press.

Republic Engineering Cooperation (PVT) (1988). Lahore-Islamabad Motorway Project; Route Selection Study. P. H. Authority. Lahore, Government of Punjab.

Rouse, S. (1988). Agrarian Transformation in a Punjabi Village: Structural Change and its Consequences. Madison, University of Wisconsin. PhD.

Scott, J. C. (1969). "The Analysis of Corruption in Developing Nations." Comparative Studies in Society and History 11(3): 315-341.

Scott, J. C. (1972). "The Erosion of Patron-Client Bonds and Social Change in Rural Southeast Asia." The Journal of Asian Studies 32(1): 5-37.

Scott, J. C. (1972). "Patron-Client Politics and Political Change in Southeast Asia." The American Political Science Review 66(1): 91-113.

Scott, J. C. and B. J. Kerkvliet (1977). How traditional rural Patrons lose Legitimacy: A theory with Special Refernece to Southeast Asia. Friends, Followers and Factions: Reader in Political Clientelism S. W. Schmidt, University of California Press

Sen, A. (1999). Development as Freedom. New York, Knopf.

Weingrod, A. (1968). "Patrons, Patronage, and Political Parties." Comparative Studies in Society and History 10(4): 377-400.

Weingrod, A. and E. Morin (1971). "Post Peasants: The Character of Contemporary Sardinian Society." Comparative Studies in Society and History 13(03): 301-324.

World Bank (2000). Attacking Poverty. World Development Report. Washington DC, World Bank. 